\title{
Nests, Eggs, and Nestlings of the Restinga Antwren Formicivora littoralis (Aves: Thamnophilidae)
}

\author{
FLÁVIA G. CHAVES ${ }^{1}$, MAURÍCIO B. VECCHI ${ }^{2}$, THIAGO F.S. LAURINDO ${ }^{3}$ and MARIA ALICE S. ALVES ${ }^{1,2}$ \\ ${ }^{1}$ Programa de Pós-graduação em Ecologia e Evolução, Departamento de Ecologia, \\ Instituto de Biologia Roberto Alcantara Gomes, Universidade do Estado do Rio de Janeiro, \\ Rua São Francisco Xavier, 524, 20550-011 Rio de Janeiro, RJ, Brasil \\ ${ }^{2}$ Departamento de Ecologia, Instituto de Biologia Roberto Alcantara Gomes, \\ Universidade do Estado do Rio de Janeiro, Rua São Francisco Xavier, 524, 20550-011 Rio de Janeiro, RJ, Brasil \\ ${ }^{3}$ Iniciação Científica, Departamento de Ecologia, Instituto de Biologia Roberto Alcantara Gomes, \\ Universidade do Estado do Rio de Janeiro, Rua São Francisco Xavier, 524, 20550-011 Rio de Janeiro, RJ, Brasil
}

Manuscript received on June 28, 2011; accepted for publication on October 10, 2011

\begin{abstract}
We describe the nest, eggs, and nestlings of the Restinga Antwren (Formicivora littoralis), an endangered bird of Restinga ecosystem (sandy coastal plain vegetation) that is endemic to Rio de Janeiro state. Twelve nests were found at the edges of trails or natural gaps at Massambaba Restinga region, in different supporting plants and heights from the ground $(\mathrm{X} \pm \mathrm{SD} 1.27 \pm 0.97 \mathrm{~m}$, range 0.27 to $3.45 \mathrm{~m}$ ). Nests were cup-shaped and were in horizontal forks attached to branches at three to five points with whitish, soft, and thin cotton-like vegetable fiber. The nests' cup shape and measurements were similar to congeneric species, but nest material was different. Eggs were white with brown spots concentrated on the large end or around the middle, giving the appearance of a rough brown ring. Their mean $( \pm \mathrm{SD})$ minimum diameter was $13.1 \pm 0.34 \mathrm{~mm}$, with maximum diameter of $18.0 \pm 0.38 \mathrm{~mm}$, and mass of $1.7 \pm 0.18 \mathrm{~g}$ $(n=8)$. We found two nestlings completely naked on their first day after hatching.
\end{abstract}

Key words: Atlantic Forest, Brazil, breeding, conservation, endemic, Passeriformes.

\section{INTRODUCTION}

The genus Formicivora is comprised of seven species restricted to Central and South America (Zimmer and Isler 2003), two of which are considered Globally Endangered (IUCN 2012): Black-hooded Antwren (F. erythronotos) and Restinga Antwren (F. littoralis). Nests of species of this genus have been described as: F. grisea (Pinto 1953), F. erythronotos (E.C. Mendonça, unpublished data), F. rufa (Willis and Oniki 1988), and F. melanogaster (Zimmer and Isler 2003).

Correspondence to: Maria Alice dos Santos Alves

E-mail:masaal@globo.com
Formicivora littoralis is considered the only bird endemic to the Restinga habitat (sandy coastal plain vegetation) (Gonzaga and Pacheco 1990). This species has a small range, only inhabiting the area in the state of Rio de Janeiro between the municipalities of Saquarema and Armação dos Búzios (Mattos et al. 2009). The little scientific information about this species in the literature mostly addresses its ecology, conservation, and distribution (Gonzaga and Pacheco 1990, Tobias and Williams 1996, Vecchi and Alves 2008). Mattos et al. (2009) have recently presented 
more detailed information on the distribution and abundance estimates of this species. Our objective is to present a description of the nests, eggs, and nestlings of the Restinga Antwren.

\section{MATERIALS AND METHODS}

\section{STUDY AREA}

Our field work was conducted at Massambaba Restinga (22 ${ }^{\circ} 56^{\prime} 21.9^{\prime}$ ' S, 42 $2^{\circ} 17^{\prime}$ 58.0” W), District of Praia Seca in the municipality of Araruama, state of Rio de Janeiro, Brazil. Massambaba Restinga is pristine area of restinga habitat mostly included in Parque Estadual da Costa do Sol, a recently created state reserve. This area is composed of scrub and arboreal vegetation $(\sim 1-7 \mathrm{~m}$ height $)$, which is rich in bromeliads and cacti.

We searched monthly for nests throughout 2008, 2010 and 2011 (January to June), using 17 hand-made trails due to the difficulty in penetrating the scrub and dense vegetation. Nest measurements, taken just after the nestlings fledged, were: external and internal diameters, height, depth and weight. Branches of the plants used to support the nests were collected for identification. Egg measurements included weight and minimum and maximum diameter. Nestling measurements only included body mass.

Nest, egg, and nestling measurements were made with calipers (precision $0.1 \mathrm{~mm}$ ) and a scale (Pesola $^{\circledR}$ with $0.1 \mathrm{~g}$ precision); height of nests above ground were scored using a tape measure (precision $1 \mathrm{~cm}$ ).

\section{RESULTS}

NEST DESCRIPTION

We found 12 nests at edges of trails or natural gaps (usually less than $5 \mathrm{~m}$ from the trail), in various supporting plants and heights (Table I). Nests 1 to 12 were found on, respectively: May 20, August 23, November 20 (2008), June 17, September 5, September 12, October 23 and 24 (two nests)
(2010), May 26 and June 15 (two nests) (2011) All nests were active when found (egg or nestling stages), except one nest found during the nest building stage (Table I). As we could not ensure if this nest was completely built we did not measure its diameters and depth. The nests were cupshaped and were attached in horizontal forks from three to five points (Fig. 1). Nests were attached to the branches with a soft, whitish, thin cottonlike vegetable fiber. This same material was used in different proportions to attach the nest. All nests were under branches of shrubs or trees, that provided partial protection from the sun and rain. They were externally constructed with light brown branches and fine fibers, many of which were of the cactus Pilosocereus arrabidae (Cactacea). Internally, the nests were darker, composed of fine dark brown and black tangled vines. Some nests had pieces of dry leaves, bark (some with lichens), cobwebs, and insect pupas. The nests measured (x $\pm \mathrm{SD}$ ): $1.27 \pm 0.97 \mathrm{~m}$ in height (in relation to the ground), $73.7 \pm 8.79 \mathrm{~mm}$ external diameter, 61.4 $\pm 5.43 \mathrm{~mm}$ internal diameter, $57.0 \pm 19.33 \mathrm{~mm}$ internal depth, and had a mass of $4.25 \pm 1.0 \mathrm{~g}$.

\section{EGG DESCRIPTION}

The number of eggs (all oval shaped, $n=8$ ) in the nests varied from one $(n=2)$ to two $(n=3)$. The eggs were white with brown spots concentrated on the large end or close to the middle, giving the appearance of a rough brown ring (Fig. 2). Their mean $\pm \mathrm{SD}$ minimum diameter was $13.1 \pm 0.38 \mathrm{~mm}$ with a maximum diameter of $18.0 \pm 0.34 \mathrm{~mm}$, and mass of $1.7 \pm 0.18 \mathrm{~g}(n=8)$.

\section{NESTLING DESCRIPTION}

We found nestlings in different stages, including two on the day of hatching. These two nestlings were born completely naked with closed eyes (Fig. 2) and yellow bills. Both nestlings were in the same nest and weighed 5 and $6 \mathrm{~g}$, respectively. 
TABLE I

Supporting plants and nest measurements of Formicivora littoralis in Massambaba Restinga, Rio de Janeiro, Brazil. ED = external diameter; ID = internal diameter.

\begin{tabular}{clccccc}
\hline \multirow{2}{*}{ Nest } & \multicolumn{1}{c}{ Plant support (Family) } & \multicolumn{5}{c}{ Measurements } \\
\cline { 3 - 6 } & & Height (m) & ED (mm) & ID (mm) & Depth (mm) & Weight (g) \\
\hline 1 & Erythroxylum subrotundum (Erytroxylaceae) & 0.87 & 56.9 & 54.2 & 70 & - \\
2 & Zollernia glabra (Leguminosae) & 2.76 & 75.3 & 63.7 & 60 & 3.5 \\
3 & Arrabidae conjugata (Bignoniaceae) & 1.45 & 78.5 & 65.0 & 110 & 5.0 \\
4 & Chrysophyllum lucentifolium (Sapotacea) & 1.63 & 77.4 & 65.5 & 45 & - \\
5 & Justicia brasiliana (Acanthaceae) & 0.27 & 69.9 & 61.1 & 55 & - \\
6 & Trichilia casaretti (Meliaceae) & 0.67 & 79.9 & 65.0 & 45 & - \\
7 & Myrrhinium atropurpureum (Myrtaceae) & 0.91 & 63.0 & 54.0 & 55 & - \\
8 & Aspidosperma parsifolium (Apocynaceae) & 1.45 & 76.0 & 60.0 & 49 & - \\
9 & Cyanophalla flexuosa (Capparaceae) & 1.08 & 74.0 & 57.5 & 44 & - \\
10 & Chrysophyllum lucentifolium (Sapotacea) & 0.39 & 70.0 & 58.0 & 43 & - \\
11 & Eugenia umbelliflora (Myrtacea) & 3.45 & - & - & - & - \\
12 & Justicia brasiliana (Acanthaceae) & 0.40 & 90.0 & 72.0 & 52 \\
\hline
\end{tabular}

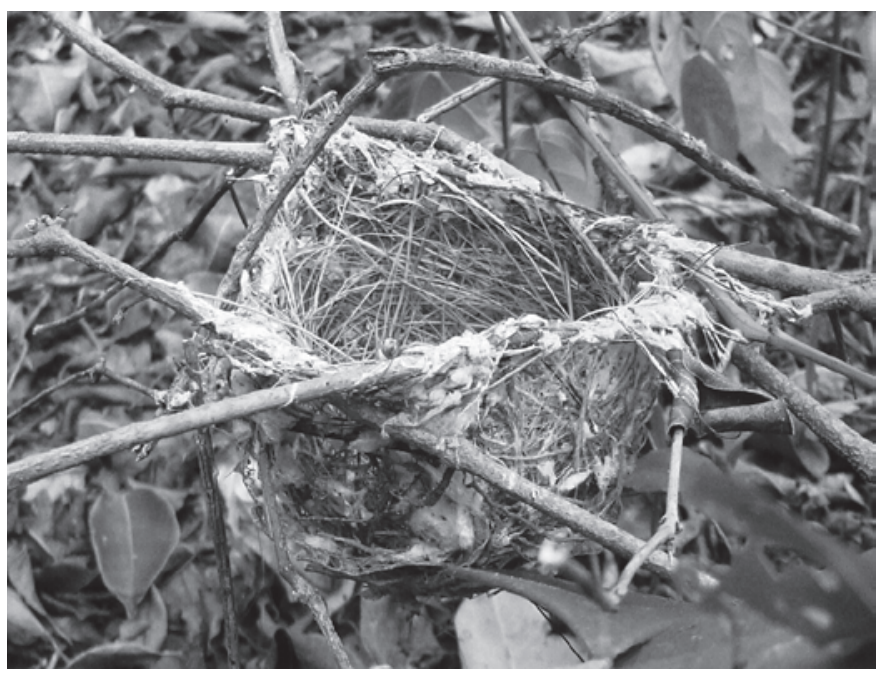

Fig. 1 - Formicivora littoralis nest. Photograph by Flávia Chaves.

\section{DISCUSSION}

Nests of the Restinga Antwren were similar to the form (cup) of other species of the family. We followed Simon and Pacheco (2005), and categorized the cup form as low cup/fork, because the external height was less than the external diameter.

The nests varied from 0.27 to $3.45 \mathrm{~m}$ in height above ground level with the majority $(n=9)$ above $0.5 \mathrm{~m}$. M. Soneghet (unpublished data) provided a minimal amount of information on nest height of this species ( 1.7 to $2.1 \mathrm{~m}, n=3$ ). Besides that, C.H.P. Oliveira (unpublished data) and also A.Q. Navegantes (unpublished data) found only one nest each close to the soil level ( $\sim 0.5 \mathrm{~m}$ or less) (Table II). Nests of Formicivora vary in terms of height. Data for F. grisea (Silva 1988; $n=1$ ), F. rufa (Willis and Oniki 1988; $n=1$ ), F. melanogaster (Zimmer and Isler 2003; $n=2$ ), and F. erythronotos (E.C. Mendonça, unpublished data; $n=19$ ) indicate nests are found on average $0.55 \mathrm{~m}$ from the ground. All nests of 


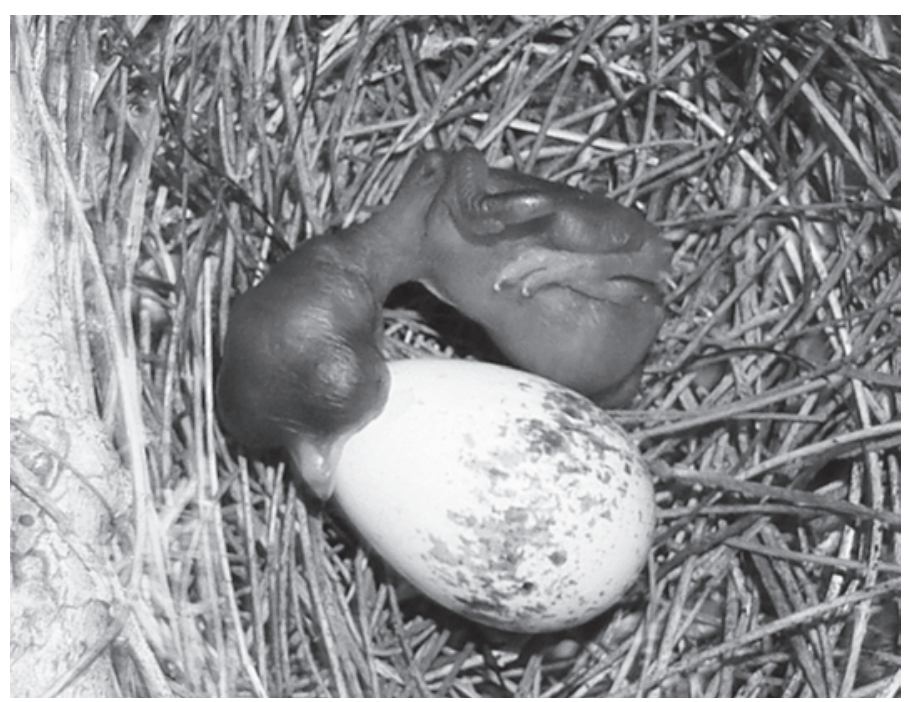

Fig. 2 - Formicivora littoralis egg and first day nestling. Photograph by Luiz Freire.

F. erythronotos, despite the comparatively high sampled number, were less than $1 \mathrm{~m}$ above ground.

Our data are similar to those for congeneric species (Table II). There was no apparent relation between nest building and supporting plants. Despite all nests were found near trails and natural gaps, it is not clear if there was microhabitat selection for nesting sites because dense and imbricated vegetation makes searching for nests in inner patches very difficult.
We found some differences between $F$. littoralis and congeneric species $F$. erythronotos and F. grisea, in terms of nest composition. For the latter, E.C. Mendonça (unpublished data) and Silva (1988) reported the presence of bryophytes in the external area of the nests. This material was absent in the 12 nests we found in the present study. The dried and dead leaves, lichens, and the cottonlike material we found in F. littoralis nests were not recorded for F. erythronotos or F. grisea.

TABLE II

Nest measurements of the genus Formicivora. ED = external diameter; ID = internal diameter.

The measurements are given in averages, except for M. Soneghet 1991 (unp. data) (range).

* For F. erythronotos, $\mathrm{n}=19$ (height, ED), 18 (ID) and 20 (depth).

\begin{tabular}{ccccccc}
\hline Species & $\mathbf{n}$ & Height $(\mathbf{m})$ & ED $(\mathbf{m m})$ & ID $(\mathbf{m m})$ & Depth $(\mathbf{m m})$ & Reference \\
\hline F. littoralis & 12 & 1.27 & 73.7 & 61.4 & 57.0 & Present study \\
F. littoralis & 3 & $1.7-2.1$ & $80-90$ & $60-70$ & $50-60$ & M. Soneghet (unp. data) \\
F. littoralis & 1 & $<0.5$ & $87 \times 67$ & $63 \times 51$ & 48 & A.Q. Navegantes (pers. comm.) \\
F. littoralis & 1 & 0.54 & - & - & - & C.H.P. Oliveira (unp. data) \\
F. grisea & 1 & 0.5 & $90 \times 70$ & - & 75 & Silva 1988 \\
F. rufa & 1 & 0.2 & 70 & 60 & 48 & Willis and Oniki 1988 \\
F. erythronotos & $*$ & 0.53 & 68 & 51 & 49 & E.C. Mendonça (unp. data) \\
F. melanogaster & 2 & 0.16 & 60 & - & 30 & Zimmer and Isler 2003 \\
\hline
\end{tabular}


TABLE III

Mean egg measurements in Formicivora. * $n$ not reported.

\begin{tabular}{lcccc}
\hline Species & n & Max & Min & Reference \\
\hline F. littoralis & 8 & 18.0 & 13.1 & Present study \\
F. littoralis & $*$ & 21.5 & 14 & M. Soneghet (unp. data) \\
F. grisea & 5 & 18 & 13 & Pinto 1953 \\
F. rufa & 1 & 20 & 14 & Willis and Oniki 1988 \\
F. erythronotos & 35 & 13.7 & 13.2 & E.C. Mendonça (unp. data) \\
\hline
\end{tabular}

The eggs in our study were similar in coloration, patch distribution, and measurements of congeneric species. The maximum diameter of F. littoralis eggs was slightly larger than that of F. erythronotos (Table III).

Two nestlings were found on the first day after hatching. They were completely naked, contradicting M. Soneghet (unpublished data), who reported that nearly hatched nestlings were covered by a dark brown plumage, similar to the female plumage. It is possible that Soneghet had found nestlings a few days after hatching. There is no information available about this issue for other species of Formicivora.

This article provides valuable information on nests, eggs and nestlings of a Critically Endangered species, Formicivora littoralis. The original information we presented in this paper is important to understand life history strategies and demography of the species. It certainly will contribute for increase the knowledge on the ecology of F. littoralis and help to support future actions in terms of its conservation.

\section{ACKNOWLEDGMENTS}

We would like to thank Fabio Silva, Vera Pittigliani, Reynaldo Fortes and Luzia Fortes for logistical support and friendship. Clinton N. Jenkins helped with the revision in English. Several colleagues of the Laboratório de Ecologia de Aves (DECOL/ UERJ) helped with the field work. SAVE Brasil and Conservation International Brazil for financial support, as well as Cyl Farney C. Sá and Adriana C. Sá (Botanical Garden of Rio de Janeiro) for plant species identification. Luiz Freire kindly provided the photograph of Fig. 2. Idea Wild donated equipment and government for research scholarships for authors (CNPq for F. G. C., M. A. S. A. - process 148581/2010-2 and 308792/2009-2, respectively, and FAPERJ for M. B. V. - process E-26/100.162/2008), and also a grant to M. A. S. A. (process no. E-26/102.837/2012).

\section{RESUMO}

Nós descrevemos ninho, ovos e ninhegos do formigueirodo-litoral (Formicivora littoralis), uma ave ameaçada do ecossistema de Restinga (vegetação de planícies arenosas costeiras) que é endêmica do Estado do Rio de Janeiro. Doze ninhos foram encontrados nas bordas de trilhas ou clareiras naturais na região da Restinga da Massambaba, em diferentes plantas suporte e alturas sobre o solo ( $\mathrm{X} \pm$ DP 1,27 $\pm 0,97 \mathrm{~m}$, amplitude $0,27 \mathrm{a}$ $3,45 \mathrm{~m}$ ). Os ninhos tiveram forma de cesto e estavam em forquilhas horizontais, presos a galhos em três a cinco pontos com fibra vegetal esbranquiçada, macia e fina, semelhante a algodão. A forma de cesto e as medidas dos ninhos foram semelhantes às de espécies congêneres, mas o material do ninho foi diferente. Os ovos foram brancos com manchas marrons concentradas na extremidade mais larga ou na porção mediana, dando a aparência de um anel rudimentar marron. A média \pm DP do diâmetro menor foi $13,1 \pm 0,34 \mathrm{~mm}$, com diâmetro máximo de 18,0 $\pm 0,38 \mathrm{~mm}$, e massa de 1,7 $\pm 0,18 \mathrm{~g}$ $(n=8)$. Nós encontramos dois ninhegos completamente nús, em seu primeiro dia de nascidos.

Palavras-chave: Mata Atlântica, Brasil, reprodução, conservação, endemismo, Passeriformes.

\section{REFERENCES}

GONZAGA LP AND PACHECO JF. 1990. Two new subspecies of Formicivora serrana (Hellmayr) from southeastern Brazil, and notes on the type locality of Formicivora deluzae Ménétries. Bull B O C 110: 187-193.

IUCN [ONLINE]. 2012. IUCN Red List of Threatened Species. Version 2010.2. www.iucnredlist.org (07 May 2013). 
MATTOS JCF, VALE MM,VECCHI MB AND ALVES MAS. 2009. Abundance, distribution and conservation of the Restinga Antwren Formicivora littoralis (Aves: Thamnophilidae). Bird Conserv Intern 19: 392-400.

PINTO OMO. 1953. Sobre a coleção Carlos Estevão de peles, ninhos e ovos de Belém, Pará. Pap Avulsos Zool 11: 113-224.

SILVA JMC. 1988. Aspectos da Ecologia e Comportamento de Formicivora g.grisea (Boddaert, 1789) (Aves: Formicariidae) em ambientes amazônicos. Rev Bras Biol 48: 797-805.

SIMON JE AND PACHECO S. 2005. On the standardization of nest descriptions of neotropical birds. Rev Bras Ornit 13: $143-154$

TOBIAS JA AND WILLIAMS RSR. 1996. Threatened Formicivora antwrens of Rio de Janeiro State, Brazil. Cotinga 5: 62-66.
VECCHI MB AND ALVES MAS. 2008. New records of the Restinga Antwren Formicivora littoralis Gonzaga and Pacheco (Aves, Thamnophilidae) in the state of Rio de Janeiro, Brazil: inland extended range and threats. Braz J Biol 68: 391-395.

WiLlis EO AND ONIKI Y. 1988. Nesting of the Rusty-backed Antwren, Formicivora rufa (Wied 1831) (Aves, Formicariidae). Rev Bras Biol 48: 635-637.

ZIMMER KJ AND ISLER ML. 2003. Family Thamnophilidae (typical antbirds). In: DEL HOYO J, ELLIOTT A AND CHRISTIE DA (Eds), Handbook of the birds of the world, Lynx Editions, Barcelona, Spain, p. 448-681. 